\title{
Which Operations of Musculoskeletal Tumors Should Be Accompanied by A Vascular Surgeon?
}

\section{Hangi Muskoloskeletal Tümörlerin Cerrahisine Damar Cerrahı Eşlik Etmelidir?}

\author{
Ahmet Yıldırım¹, Recep Öztürk², Şefik Murat Arıkan², Ahmet Fevzi Kekeç³, İlknur Bahar Günaydın \\ ${ }^{1}$ Selçuk Üniversitesi Tıp Fakültesi, Ortopedi ve Travmatoloji Anabilim Dalı, Konya, Türkiye \\ ${ }^{2}$ Ankara Dr Abdurrahman Yurtaslan Onkoloji Eğitim Araştırma Hastanesi, Ortopedi Ve Travmatoloji Anabilim \\ Dalı, Ankara, Türkiye \\ ${ }^{3}$ Necmettin Erbakan Üniversitesi Meram Tıp Fakültesi, Ortopedi ve Travmatoloji Anabilim Dalı, Konya, \\ Türkiye \\ ${ }^{4}$ Türkiye Yüksek İhtisas Eğitim ve Araştırma Hastanesi, Kalp Damar Cerrahisi Anabilim Dalı, Ankara, Türkiye \\ Dergiye Ulaşma Tarihi:01/07/2018 Dergiye Kabul Tarihi:27/08/2018 Doi: 10.5505/aot.2018.10337
}

\section{ÖZET}

GİRIŞ ve AMAÇ: Kas iskelet sistemi benign ve malign tümörleri, önemli nörovasküler yapılarla ilişkili olabilmektedir ve uygulanan bazı cerrahi prosedürlere damar cerrahı da eşlik etmektedir. Bu çalışmada, nörovasküler yapılarla ilişkili olabilen tümörlerin demografik incelenmesi amaçlanmıştır. YÖNTEM ve GEREÇLER: 2010-2014 yılları arasında Dr. Abdurrahman Yurtaslan Onkoloji Eğitim Araştırma Hastanesiortopedi ve travmatoloji kliniğinde, kas iskelet sistemi tümörü nedenli ile ameliyat edilen ve ameliyata kardiyovasküler cerrahın eşlik ettiği 58 hasta çalışmaya dahil edildi. Hastalar yaş, cinsiyet, benign/malign olması, kemik-yumuşak doku yerleşimi, histopatolojik tanı ve tümör lokalizasyonu açısından incelendi. BULGULAR: Ortalama yaşı 36 \pm 0,17 (2-76 yaş arası) olan 30 erkek ve 28 kadın hastanın 15 sında benign, 43 sinde malign tümör mevcuttu. En sık görülen tümör malign mezenkimal tümör idi ve 14 vakada görüldü. En sık görülen benign tümör, 6 vakada görülen osteokondromdu. En sık tutulan lokalizasyon, uyluk ve diz bölgesi idi. TARTIŞMA ve SONUÇ: Nörovasküler yapılara yakınlık gösteren ve kardiyovasküler cerrahın operasyona eşlik ettiği tümörler, geniş bir yaş aralığında görülebilmektedir. Sıklıkla malign tümörlerdir. En sık uyluk ve diz lokalizasyona yerleşirler.

Anahtar Kelimeler: damar cerrahisi, muskuloskeletal tümörler, nörovasküler tutulum, cerrahi tedavi

\begin{abstract}
INTRODUCTION: Benign and malign tumors of the musculoskeletal system may be related with thecritical neurovascular structures. Therefore, some surgical procedures are applied with cardiovascular surgeons. In this study, demographic examination of the musculoskeletal tumors which might be related with neurovascular structures was aimed. METHODS: Between 2010 and 2014, 58 patients who were operated with cardiovascular surgeon due to musculoskeletal tumors in orthopedics and traumatology clinic were included in the study. Patients were examined for age, sex, benign / malignant features, bone-soft tissue location, histopathological diagnosis and tumor localization.

RESULTS: Among 30 male and 28 female patients with a mean age of $36 \pm 0,17$ (2-76 years), 15 patients had benign and 43 patients had malign musculoskeletal tumors. The most common tumor was a malign mesenchymal tumor and it was seen in 14 cases. The most common benign tumor was osteochondroma and it was found in 6 cases. The most common tumor localization with cardiovascular surgeon requirement was thigh and knee. DISCUSSION and CONCLUSION: Musculoskeletal tumors may be closely related to the neurovascular structures and therefore they are needed to beoperated with cardiovascular surgeons; can be seen in kind of ages. These are often malign tumors. The most common localizations are thigh and knee.
\end{abstract}

Keywords: cardiovascular surgeon, musculoskeletal tumors, neurovascular involvement, surgical treatment

\section{INTRODUCTION}

Vascular invasion of musculoskeletal tumors is rare. In a multicenter study, main vessel involvement was shown as $3.3 \%$ in primary bone tumors and $9.0 \%$ in soft tissue sarcomas (1). However, in patients who have extremity musculoskeletal tumors, the presence and level of vascular involvement is necessary for determination of surgical treatment (2). 
Accurate identification of the presence and level of vascular involvement is necessary for determination of surgical treatment in patients who have extremity musculoskeletal tumors. Moreover, some tumors which have rich vascularity own enlarged feeding arteries and therefore they can cause severe bleeding during surgery (3).

Magnetic resonance imaging (MRI) is the primary imaging modality for the evaluation of extremity sarcomas. Today, computed tomography (CT) and contrast-enhanced CT can often be used to determinate of tumor characteristics and resectability in patients who cannot undergo MR or in addition to MR. Several studies have examined musculoskeletal sarcomas using conventional angiography or MR angiography (2-4).

When a musculoskeletal system tumor is diagnosed, orthopeadic surgeons should carefully evaluate the lesion before surgery and should be able to determine whether radiotherapy or chemotherapy is needed to reduce the size of the tumor (5).

In this study, the patients who underwent surgical operation accompanied with cardiovascular surgeons in our clinic were retrospectively analyzed and demographic data of these cases were presented.

\section{METHOD}

Between January 2010 and December 2014, 58 patients who were operated accompanied with cardiovascular surgeons because of musculoskeletal tumors in our clinic were retrospectively analyzed.

The study was planned with the patients who had benign and malign musculoskeletal tumors. The patients who were treated with neoadjuvant chemotherapy and radiotherapy treatment also included to the study and the main goal was to identify the cardiovascular surgeon requirement for those cases.

\section{Statistical analysis}

All statistical analyzes were performed using IBM SPSS 22.0 statistical software (IBM Corp., Armonk, NY, USA). Descriptive statistics were expressed as mean \pm Standard deviation, frequency and percentage.

\section{RESULTS}

30 of the patients were male, 28 were female, and the age range was between 2-76 years. The mean age was $36 \pm 0,17$ std. 15 patients had benign tumor, 43 patients had malignant tumor. When benign tumors were evaluated, the diagnoses were osteochondroma in 6 patients, fibromatosis in 3 patients, aneurysmal bone cyst in 2 patients, solitary fibrous tumor in 2 patients, giant cell tumor of bone in 1 patient and hemangioma in 1 patient.

When malignant tumors were evaluated, 14 patients had malign mesenchymal tumors (MMT), 13 patients had osteosarcoma, 3 patients had Ewing's sarcoma, 3 patients had chondrosarcoma, 2 patients had angiosarcoma, 1 patient had synovial sarcoma, 2 patients had fibrosarcoma, 1 patient had rhabdomyosarcoma, 1 patient had soft tissue Ewing's sarcoma, 1 patient had chondromyxoid sarcoma, 1 patient had liposarcoma and 1 patient had metastasis.

When the tumor localizations were evaluated, tumor were at bone in 31 patients and were at soft tissue in 27 patients. Tumor's localization was proximal femur in 13 patients and distal femur in 10 patients, popliteal soft tissue region in 7 patients, pelvic soft tissue region in 6 patients, cubital soft tissue region in 5 patients, proximal humerus in 3 patients, distal humerus in 1 patient, axilla in 3 patients, kruris in 3 patients, ankle soft tissue in 2 patients, proximal tibia in 3 patients, proximal fibula in 1 patients and gluteal soft tissue area in 1 patient.

\section{DISCUSSION}

Complete resection improves local tumor control and survival in musculoskeletal tumors. Involvement of vascular structures during resection is very important (7). In these days, adequate surgical margins can be achieved with advanced imaging techniques, adjuvant chemotherapy and radiation protocols. Thus, there is no requirement of radical resection or amputation $(8,9)$.

If the sarcomas show vascular invasion, the vessels should be resected $(10,11)$. Soft tissue sarcomassurrounded by a plane of normal tissue can be dissected from major blood vessels. By longitudinally splitting the adventitia opposite the tumor, a rim of normal 
tissue is preserved in the vessel-tumor interface $(10,12)$. However, vascular resection increases the extent of their section margin. Therefore, vascular resection is indicated when a large resection margin cannot be achieved without vascular resection $(7,10,11)$.

In this study,it was aimed that the clinicians should be able to get an idea about that in which localizations, ages or histopathological diagnoses of the tumors are more related to blood vessels. According to our results, it cannot be said that the musculoskeletal tumors have a narrow age range in which vascular involvement is frequent. There are cases between the ages of 2 and 76 in our study.
The most common localizations in our study were thigh, femur and knee. Therefore, we know that the most commonly affected structures are femoral and popliteal vesselnerve packs. In the literature, there are studies about vessel involvement and treatment of tumors in these localizations $(7,10,14,15)$.

According to our study, the most common vessel-associated tumors are malignant mesenchymal tumors and osteosarcomas. Although osteochondromas are the most common benign tumors, they rarely show vascular complications.

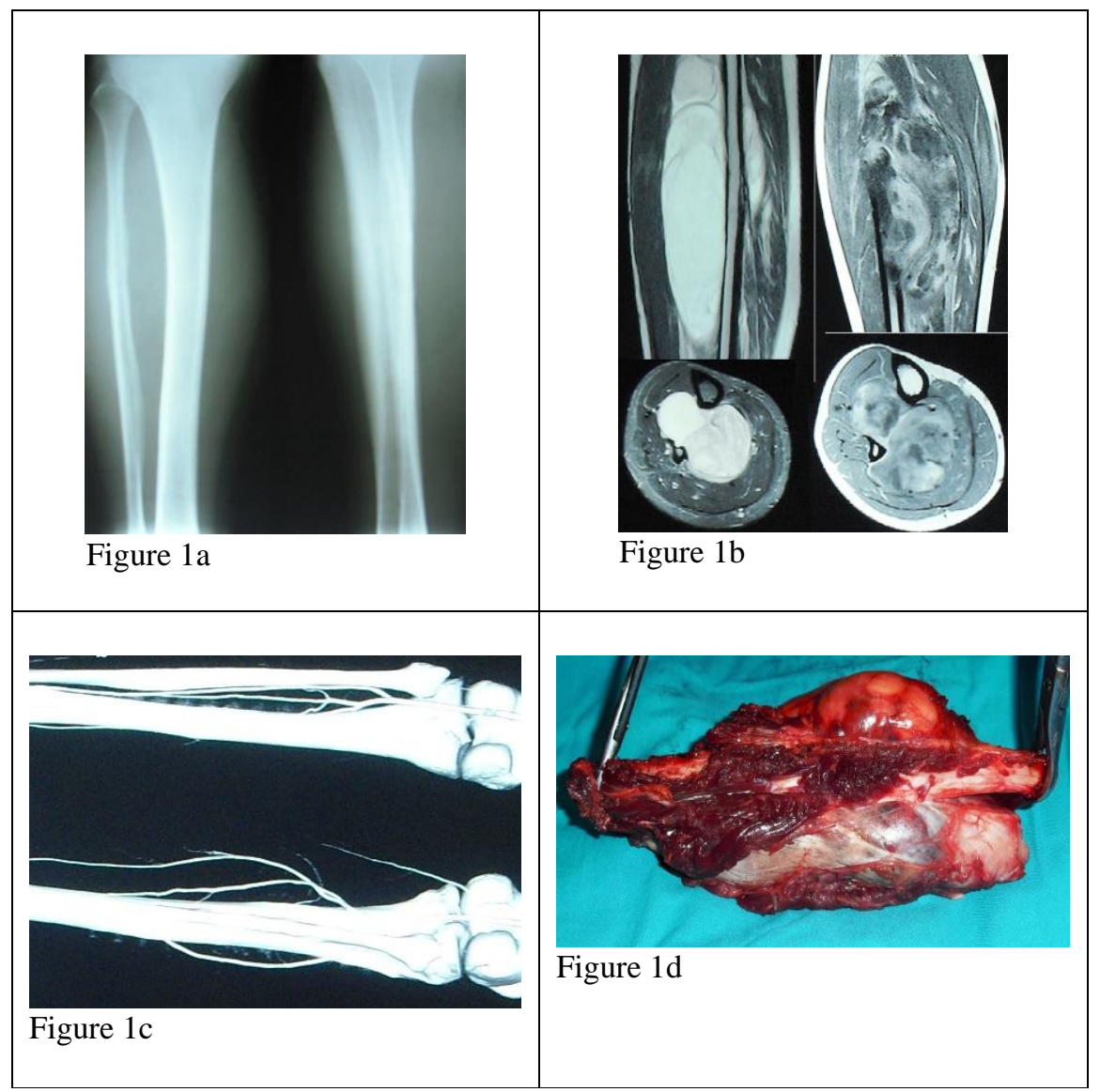

Figure 1: 30 years old male patient, liposarcoma located right cruris posterior. a) radio-opacity due to soft tissue mass in direct radiographs b) MRI sections of tumoral mass, connections between neurovascular tissues c) BT angiography images d) macroscopic view of the resected tumor, saphenous vein bypass was performed after extensive resection by orthopedics and cardiovascular surgeons

\section{CONCLUSIONS}


It is important to know which tumors and which localizations are associated with neurovascular structures. For the tumors that are close to the neurovascular structure; cardiovascular surgeon is obligatory needed. The most common tumors among these cases are malign mesenchymal tumors. The most common localizations are thigh and knee. Correct identification of the tumor and to know tumor's relation with adjacent vascular structures is very important for successful surgical operation.

\section{Conflict of interest: None}

\section{REFERENCES}

1- Panicek DM, Go SD, Healey JH, et al. Soft-tissue sarcoma involving bone or neurovascular structures: MR imaging prognostic factors. Radiology. 1997;205:871-5

2- Feydy A, Anract P, Tomeno B, et al. Assessment of vascular invasion by musculoskeletal tumors of the limbs: use of contrast-enhanced MR angiography. Radiology. 2006;238(2):611-21

3- Li Y1, Zheng Y, Lin J, et al. Evaluation of the relationship between extremity soft tissue sarcomas and adjacent major vessels using contrast-enhanced multidetector $\mathrm{CT}$ and three-dimensional volumerendered CT angiography: a preliminary study. Acta Radiol. 2013;54(8):966-72

4- Fujii J, Ozaki T, Kawai A, et al. Angiography for assessment of preoperative chemotherapy in musculoskeletal sarcomas. Clin Orthop Relat Res 1999;360:197-206

5- Canter RJ, Smith CA, Martinez SR et al. Extremity soft tissue tumor surgery by surgical specialty: a comparison of case volume among oncology and nononcology-designated surgeons. J Surg Oncol. 2013;108(3):142-7
6- Zheng W, Song S, Liang F. Major blood vessel excision and reconstruction in the treatment of retroperitoneal neoplasms. Zhonghua Zhong Liu ZaZhi. 1998;20:225-7

7- Schwarzbach $\mathrm{MH}^{1}$, Hormann $\mathrm{Y}$, Hinz U, et al. Clinical results of surgery for retroperitoneal sarcoma with major blood vessel involvement. J Vasc Surg. 2006;44(1):46-55

8- Ghert MA, Davis AM, Griffin AM, et al. The surgical and functional outcome of limb-salvage surgery with vascular reconstruction for soft tissue sarcoma of the extremity. Ann Surg Oncol. 2005;12(12):1102-10

9- Öztürk R, Aydın M, Arıkan M, et al. The report of tumor resection prosthesis infection due to Sphingomonaspaucimobilis: A case report. Acta Oncol Tur. 2016;49(1): 57-60

10- Bonardelli S, Nadari F, Maffeis R, et al. Limb salvage in lower-extremity sarcomas and technical details about vascular reconstruction. J Orthop Sci. 2000;5:555-60

11- Öztürk R, Arıkan ŞM, Şimşek MA, et al. Management of solitary fibrous tumors localized in extremity: case series and a review of the literature. Eklem Hastalik Cerrahisi. 2017;28(2):121-7

12- Ceraldi CM, Wang T-N, O’Donnell RJ, et al. Vascular reconstruction in the resection of soft tissue sarcoma. Perspect Vasc Surg 2000;12:67-83.

13- Hohenberger P, Allenberg JR, Schlag PM, et al. Results of surgery and multimodal therapy for patients with soft tissue sarcoma invading to vascular structures. Cancer 1999;85:396-408

14- Fortner JG, Kim DK, Shiu MH. Limb-preserving vascular surgery for malignant tumors of the lower extremity. Arch Surg. 1977;112(4):391-4.

15- Baxter BT, Mahoney C, Johnson PJ, et al. Concomitant arterial and venous reconstruction with resection of lower extremity sarcomas. Ann Vasc Surg. 2007;21(3):272-9 